\title{
Relationship between Motivation and Job Satisfaction with Performance
}

\author{
Ahmad Jauhari Hamid Ripki \\ \{ajharstkipkusumanegara@stkipkusumanegara.ac.id\} \\ STKIP Kusumanegara, Indonesia
}

\begin{abstract}
This research aims to determine the relationship between (1) motivation (2) job satisfaction with performance, (3) the relation between motivation and job satisfaction with performance altogether. The research method using survey by correlation approach. This research used as a sample of 80 employees, and 20 employees for testing, and selected based on a simple random technique (Simple Random Sampling). Study toward UPTD staff was conducted in each sub district, Karawang regency. Technique data collecting was using the instrument in the form of questionnaire. This instrument is calibrated with the test item validity and reliability coefficients. To test the validity of using Pearson Product Moment correlation, while the reliability coefficient is calculated using the formula of Cronbach Alpha. The implication of this research is an effort in improving the performance of employees can be done through motivation and job satisfaction.
\end{abstract}

Keywords: Relationship, motivation, job satisfaction, job performance

\section{Introduction}

The issue of education in Karawang district includes three issues: damaged school building infrastructure, education costs, and teacher quality and those issues have not been maximized.

Overcoming this problem, the district education office at the district level has a large responsibility and plays a very important role in managing human resources, which are able to compete in this globalization.

This situation occurs in the UPTD of the Department of Education of Youth and Sports Karawang regency, the low performance of employees, who have not carried out their duties to the maximum, so that the effect on the output produced.

Indirectly performance is determined by work motivation and job satisfaction, and these three factors are determinants of performance success. The high and low performance of a person is not only influenced the work motivation, and job satisfaction, this is partly characterized by a work environment that is not conducive to disrupted interpersonal relationships between employees, lack of respect for employees.

The high influence of job satisfaction of employees in the Department of Education for Youth and Sports is marked by the form of behavior, this is evidenced by the inaccurate time in completing work, low relationships between employees, lack of quality supervision from the leadership and uncomfortable working conditions, and low employee performance 


\section{Theoretical framework}

\subsection{Job performance}

Human behavior is essentially goal-oriented, in other words that the behavior is stimulated by the desires to achieve the expected goals. The basic unit of behavior is activity, so it can be concluded that all behaviors are a series of activities or activities carried out and can produce performance. Basically performance will be seen in the condition when someone do a job, because performance is a success achieved or an achievement that is shown by someone in doing their work.

Performance can be interpreted as the total result of the work done by someone for the organization which is done at any time based on a predetermined time. [1]According to salleh employee performance is the most important part of work where the level of performance will increase employee motivation According to salleh employee performance is the most important part of work where the level of performance will increase employee motivation. [2]Performance in an organization can be determined by the employees and have a willingness to give the best to the organization. [3]From various studies of theories and opinions that have been described above, it can be synthesized what is meant by performance in this study is a set of values of actions or behavior of a person in carrying out work to contribute to the achievement of organizational goals

\subsection{Motivation}

In doing all activities, the determining factors in carrying out activities are the factors of (need) factor drive (drive), and the factor of purpose (goal), whice is called motivation. In addition, motivation is essentially an impulse that is stimulated from within and from outside a person through psychological processes and individual thinking.

According to Boddy, Motivation comes from the strength that is inside or outside of someone who can generate and maintain commitment in work. Motivation comes from the Latin word movere, which means to move. But in the current context, motivation represents a psychological process that causes passion, direction, and perseverance with voluntary actions for planned goals. [3]According to Robbins and Decenzo Motivation can be interpreted as the willingness of someone to exert an effort which is to achieve the goals of an organization and strive with all the ability to satisfy his feelings[3].

\subsection{Job satisfaction}

Basically, job satisfaction is one form of employee attitudes that are shown in the organization of their work Job satisfaction is a set of attitudes toward work.

Robbins and Judge defines job satisfaction as positive feelings a person has for the results of work. [4]Job satisfaction is an employee's general attitude toward the job. The organizational rewards system often has a significant impact on the level of employee job satisfaction.According to Greenberg, Job satisfaction describes the feelings or positive or negative attitudes a person has towards the work and work environment. [1]According to Lin,An explorative study Job satisfaction comes from within employees to direct themselves and relationships with other colleagues. [5]From the study of the above theory can be synthesized what is meant by job satisfaction is a person's behavior towards feeling satisfied not satisfied with the results of his work. 


\section{Research methodology}

The target population in this study were all employees of the West Java Provincial Education Office, Affordable Population of the Karawang District Education and Youth Office. The sample was the UPTD in Karawang district as a Purposive Sampling which numbered 30 UPTD with a total of around 210 employees as Sampling frames, 20 employees from Sampling frames were used as trials, and 80 employees from Sampling frames as samples were selected by Simple Random Sampling (SRS) using the standard error formula $\frac{\sigma}{\sqrt{n}}$. Tocollect quantitative data, a measurement tool is needed that is able to answer the problems in this study. In this study using statements in the form of questionnaires. The data collected was obtained from each respondent based on their assessment. The research instrument consists of three types, namely: (1) Work Motivation Questionnaire, (2) Job Satisfaction, and (3) Performance (https://osf.io/mx35a/).

\section{Hypothesis}

Based on various theoretical studies above, it can be synthesized

a) There is a positive relationship between the motivation to job performance

b) There is a positive relationship between job satisfaction to job performance

c) There is a positive relationship between motivation and job satisfaction together with the work discipline.

\section{Research}

\subsection{Data description}

Tabel 1. Job Performance Variables (Y)

\begin{tabular}{lc}
\hline Information & Job Performance \\
\hline Mean & 127,77 \\
Median & 126,50 \\
Mode & 125,00 \\
Standard Deviation & 7,77 \\
Minimum & 108 \\
Maximum & 146 \\
Count & 149 \\
\hline
\end{tabular}

Based on the data that has been collected, regarding the performance, the lowest value is 108 and the highest value is 146, mean 127.77, Mode 125, Median 126.5 and standard deviation 7.77

Tabel 2. Motivation (X1)

\begin{tabular}{lc}
\hline Information & Motivation \\
\hline Mean & 123,75 \\
Median & 123,00
\end{tabular}




\begin{tabular}{lc} 
Mode & 124,00 \\
Standard Deviation & 11,39 \\
Minimum & 95 \\
Maximum & 150 \\
Count & 150 \\
\hline
\end{tabular}

Based on the data that has been collected, regarding the performance, the lowest value is 95 and the highest value is 150, the mean (mean) 123.75, the Median 123 mode 124 and the standard deviation 11.39

Tabel 3. Job Satisfaction (X2)

\begin{tabular}{lc}
\hline Information & Job Satisfaction \\
\hline Mean & 123,75 \\
Median & 129,00 \\
Mode & 125,00 \\
Standard Deviation & 8,31 \\
Minimum & 108 \\
Maximum & 149 \\
Count & 149 \\
\hline
\end{tabular}

Based on the data that has been collected, regarding job satisfaction, the lowest value is 108 and the highest value is 149 , the mean (mean) is 129.44 , mode 125 , Median 129, and the standard deviation is 8.31

\section{Test analysis requirements}

\subsection{The results of the research and discussion}

In testing the normality of the data, using the liliefors method, the result shows $\mathrm{L}_{\text {account }}<\mathrm{L}_{\text {tabel }}$, then $\mathrm{H} 0$ states that the distribution of normal distribution scores is rejected, and vice versa $\mathrm{H} 1$ is accepted.

\begin{tabular}{lllll}
\hline No & Estimeted error & Lcount & Ltable & Info \\
\hline 1 & Y atas X1 & 0,050 & 0,115 & Normal \\
2 & Y atas X2 & 0,052 & 0,115 & Normal \\
\hline
\end{tabular}

\subsection{Linearity and significancy test}

Tabel 5. List of ANOVA for testing Significance and Linearity Regression $\hat{\mathrm{Y}}=74,72+$ $0,429 \times 1$

\begin{tabular}{lllllll}
\hline $\begin{array}{l}\text { source of } \\
\text { variance }\end{array}$ & $\mathrm{dk}$ & $\begin{array}{l}\text { Number of } \\
\text { squares (JK) }\end{array}$ & $\begin{array}{l}\text { Average } \\
\text { Number } \\
\text { of square }\end{array}$ & Fcount & $\begin{array}{l}\text { Ftable } \\
\alpha=0,05\end{array}$ & $\begin{array}{l}\text { Ftable } \\
\alpha=0,01\end{array}$ \\
\hline $\begin{array}{l}\text { Total } \\
\text { Regresi (a) }\end{array}$ & $\begin{array}{l}\text { 80 } \\
1\end{array}$ & 1310888 & & & & \\
Regresi & 1 & 1806116,05 & & & & \\
\hline
\end{tabular}




\begin{tabular}{lrrrrrr} 
(b/a) & & & & & & \\
Residu & 78 & 2889,66 & 37,05 & & & \\
$\begin{array}{l}\text { Tuna } \\
\text { cocok }\end{array}$ & 43 & 1287,33 & 29,94 & $0,65 n s$ & 1,71 & 2,13 \\
$\begin{array}{l}\text { Estimeted } \\
\text { error }\end{array}$ & 35 & 1602,33 & 45,78 & & & \\
\hline
\end{tabular}

$* *$ :Regression is very significant, $\mathrm{F}_{\text {hitung }}>_{\text {Ftabel }}=50,81>7,01$ pada $\alpha=0,01$

ns: Linear regression, $F_{\text {hitung }}<F_{\text {tabel }}=0,65>2,13$ pada $\alpha=0,01$

dk: Degree of Freedom

Tabel 6. List of ANOVA for testing Significance and Linearity Regression $\hat{Y}=59,14+$ $0,530 \times 2$

\begin{tabular}{|c|c|c|c|c|c|c|}
\hline $\begin{array}{l}\text { source of } \\
\text { variance }\end{array}$ & $\mathrm{dk}$ & $\begin{array}{l}\text { Number of } \\
\text { squares } \\
(\mathrm{JK})\end{array}$ & $\begin{array}{l}\text { Rata-rata Jumrah } \\
\text { Kuadrat (RJK) }\end{array}$ & Fcount & $\begin{array}{l}\text { Ftable } \\
\alpha=0,05\end{array}$ & $\begin{array}{l}F_{\text {table }} \\
\alpha= \\
0,01\end{array}$ \\
\hline Total & 80 & 1310888 & & & & \\
\hline $\begin{array}{l}\text { Regresi } \\
\text { (a) }\end{array}$ & 1 & 1306116,05 & & & & \\
\hline $\begin{array}{l}\text { Regresi } \\
\text { (b/a) }\end{array}$ & 1 & 1534,44 & 1534,44 & $36,97 * *$ & 3,98 & 7,01 \\
\hline Residu & 78 & 3237,51 & 41,51 & & & \\
\hline $\begin{array}{l}\text { Tuna } \\
\text { cocok }\end{array}$ & 32 & 1179,06 & 36,85 & $0,82^{\mathrm{ns}}$ & 1,71 & 2,13 \\
\hline $\begin{array}{l}\text { Estimeted } \\
\text { error }\end{array}$ & 46 & 2058,45 & 44,75 & & & \\
\hline
\end{tabular}

**: Regresi Regression is very significant, $\mathrm{F}_{\text {hitung }}>\mathrm{F}_{\text {tabel }}=36,97>7,01$ pada $\alpha=0,01$

ns: Linear regression, $F_{\text {hitung }}<F_{\text {tabel }}=0,82>2,13$ pada $\alpha=0,01$

dk: Degree of Freedom

Tabel 7. Double Regression Coefficient Analysis $\hat{Y}=41.73+0.327 \mathrm{X} 1+0.355 \mathrm{X} 2$.

\begin{tabular}{|c|c|c|c|c|c|c|}
\hline \multirow{2}{*}{$\begin{array}{l}\text { source of } \\
\text { variance }\end{array}$} & \multirow[t]{2}{*}{$\mathrm{dk}$} & \multirow{2}{*}{$\begin{array}{c}\text { Number of squares } \\
(\mathrm{JK})\end{array}$} & \multirow{2}{*}{$\begin{array}{l}\text { Average Number } \\
\text { of squares } \\
\text { (RJK) }\end{array}$} & \multirow[t]{2}{*}{ Fcount } & \multicolumn{2}{|c|}{ Ftable } \\
\hline & & & & & 0.05 & 0.01 \\
\hline Total & 80 & 1310888 & & & & \\
\hline Regresi & 2 & 2463.21 & 1231.60 & $41.08 * *$ & 3.13 & 4.92 \\
\hline Residu & 77 & 2308.74 & 29.98 & & & \\
\hline
\end{tabular}

Tabel 8. Product Moment Correlation Calculation Results

\begin{tabular}{|c|c|c|c|c|c|c|}
\hline \multirow[t]{2}{*}{ No } & \multicolumn{2}{|c|}{ Research variable } & \multirow[t]{2}{*}{ Rxy } & \multirow[t]{2}{*}{$\mathrm{T}_{\text {count }}$} & \multirow[t]{2}{*}{$\mathrm{T}_{\text {table }}$} & \multirow[t]{2}{*}{ Conclusion } \\
\hline & Free & Bound & & & & \\
\hline 1 & $\mathrm{X} 1$ & $\mathrm{Y}$ & 0,628 & 7,13 & 2,66 & Significant \\
\hline 2 & $\mathrm{X} 2$ & Y & 0,567 & 6,08 & 2,66 & Significant \\
\hline
\end{tabular}




\section{Conclusion}

Based on data from the previous research results, with all data analysis requirements including, test homogeneity, linearity, regression significance, conclusions can be taken as First, there is a positive and very significant relationship between motivation and performance. That is, if motivation gets higher, then performance will increase.Secondthere is a positive and significant relationship between job satisfaction and performance. This means that if job satisfaction is higher, then performance will increase.

\section{References}

[1]A. Ouedraogo and A. Leclerc, "Job Satisfaction and Organizational Performance: Evidence from Canadian Credit Union," Journal of Organizational Culture, Communications and Conflict, 2013.

[2]N. S. Mohd Said, et al., "Relationship between Employee Motivation and Job Performance: A Study at Universiti Teknologi MARA (Terengganu)," Mediterranean Journal of Social Sciences, 2015.

[3]D. N. Sharma and M. A. Sharma, "Relationship Between Employee Motivation And Performance Of The Employees Working In Retail Sector In Jaipur," Journal of Management Engineering and Information Technology (JMEIT), vol. 4, 2017.

[4]A. Anggarwati and A. Eliyana, "The Influence of Creative Self-Efficacy towards Creativity with Job Satisfaction as Intervening Variable at PT. Smile Island Surabaya," International Journal in Economics and Business Administration, vol. III, 2015

[5]A. S. Bin and A. S. B. Shmailan, "The relationship between job satisfaction, job performance and employee engagement: An explorative study," Issues in Business Management and Economics, vol. 4, 2017. 